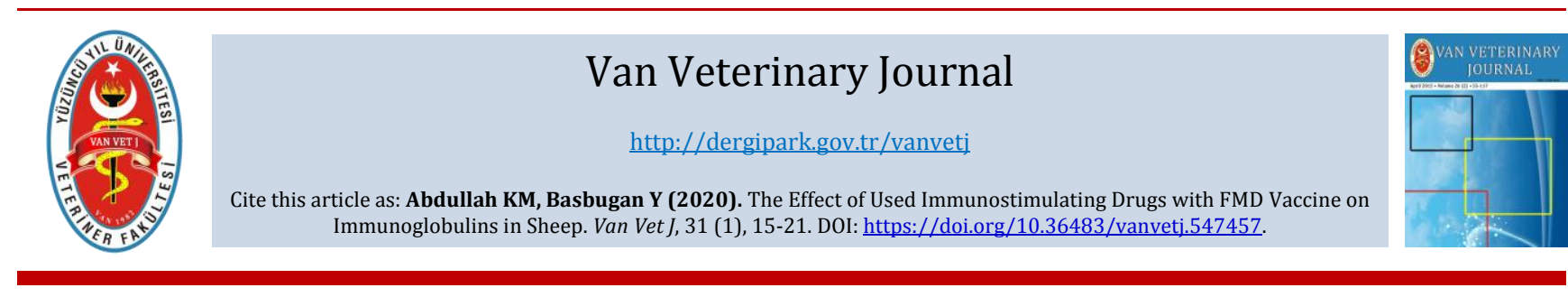

\title{
The Effect of Used Immunostimulating Drugs with FMD Vaccine on Immunoglobulins in Sheep
}

\author{
Karzan Mohammed ABDULLAH ${ }^{*}(\mathbb{D})$ Yıldıray BAȘBUĞAN2(i)
}

\begin{abstract}
${ }_{1}$ Pebaz Veterinary, Directory of GarmianVeterinary, Ministry of Agriculture and Water resources, Iraq.
${ }^{2}$ Van Yuzuncu Yil University, Faculty of Veterinary Medicine, Department of Internal Medicine, Van, Turkey
\end{abstract}

ABSTRACT In this study, the effect of used immunostimulating drugs with FMD vaccine on immunoglobulins was aimed to investigate in sheep. For this purpose 40 healthy sheep were divided into 4 groups. Blood and serum samples were taken from all animals from 0 days before the study. Blood samples were measured immediately, and IgA, IgG, IgM, IgE and Zn values from biochemical parameters were stored for measurement. Group I was applied only FMD vaccine, group II Levamisole with the FMD vaccine, group III Zinc with FMD vaccine and the last group IV $\mathrm{AD}_{3} \mathrm{E}$ was applied with FMD vaccine. After 21 days, blood and serum samples from all groups were taken again and hematologic and IgA, IgG, IgM, IgE and Zn values were compared according to the values of day 0 . No statistical difference was found between the groups except for PLT in hematological parameters ( $p>0,05)$ when compared to pre-vaccination and post-vaccination. In groups II and III there was a significant increase in PLT levels. Biochemical analysis showed IgA, IgG, IgM and IgE levels to be higher in IgG $(p<0,05)$ and $\operatorname{IgE}(p<0,001)$ in groups II and III when levels compared to before vaccination. There were statistically significant increases in IgM $(\mathrm{p}<0.05)$ in group IV.

Keywords: FMD, Immunoglobulin, Immunostimulant Drugs, Sheep

ÖZ

\section{Koyunlarda Şap Aşısı ile Birlikte Kullanılan İmmunstimülan İlaçların İmmunglobulinler Üzerine Etkisi}

Koyunlarda şap aşısı ile birlikte kullanılan immunstimülan ilaçların immunglobülinler üzerine etkisi araştırıldı. Bu amaçla 40 adet sağlıklı koyun 4 gruba ayrıldı. Çalışma öncesinde tüm hayvanlardan 0. gün kan ve serum örnekleri alındı. Hematolojik parameterler hemen ölçüldü, biyokimyasal parametrelerden IgA, IgG, IgM, IgE ve Zn değerleri ölçülmek üzere serumlar saklandı. I. gruba sadece şap aşısı uygulandı, II. gruba şap aşısı ile birlikte Levamizol, III. gruba şap aşısı ile birlikte Çinko ve son grup olan IV. gruba da şap aşısı ile birlikte AD3E vitamini uygulandı. 21gün sonra tüm gruplardan kan ve serum örnekleri tekrar alındı ve 0 . gün değerlerine göre hem hematolojik hem de IgA, IgG, IgM, IgE ve Zn değerleri kıyaslandı. Hematolojik parametrelerin PLT ve NEU hariç gruplar arasında herhangi bir istatistiksel fark belirlenmedi. 0. ve 21. günlere göre kıyaslamada II. ve III. gruplarda PLT düzeylerinde önemli artış $(p<0.05)$ tespit edilirken IV. grupta NEU duzeyinde istatistiksel olarak azalma görüldü $(\mathrm{p}<0.05)$. Biyokimyasal analizlerden IgA, IgG, IgM, IgE değerlerinde, 0 . güne göre II. Grupta $\operatorname{IgG}(p<0,05)$ ve $\operatorname{IgE}(p<0,001)$, III. grupta $\operatorname{Ig} M(p<0,05), \operatorname{IgE}(p<0,001)$ ve IV. grupta sadece IgE ( $<<0,001)$ düzeylerinde artis belirlendi. Gruplar arası kıyaslamada da II. ve III. grup IgG düzeyleri kontrol grubuna göre artış belirlendi $(p<0,05)$. Sonuç olarak Şap aşısı ile birlikte kullanılan levamizole veya çinko uygulanmasının hayvanlarda özellikle IgG ve IgM üzerine olumlu etkilerinin olduğu, aşı ile birlikte bu ilaçların uygulanmasının tavsiye edilebileceği kanısına varıldı.

Anahtar Kelimeler: FMD, Immunglobülin, Immunostimülantlar, Koyun, Şap

\section{INTRODUCTION}

Foot and mouth disease (FMD) is a sever infectious disease of the animals especially ruminant caused by a small, positive-sense RNA virus in the Genus Aphthovirus, Family Picor-naviridae, seven serotypes virus include (SAT1, 0, SAT2, A, C, Asia 1 and SAT) characterised by high fever, vesicles on the tongue, mucosa and feet, sudden death in young (Barnett et al. 2002; Wong et al. 2003; Ko et al. 2012; Horsington et al. 2015).

The disease can distribute by contact with animals infected with disease directly, or via contacted with contaminated animal products like during feeding or during drinking 
water from the same pool because virus shed mostly in saliva. In ruminants, virus may persist beyond 28 days in the oropharynx of animals for months to years (Paton et al. 2014). Susceptible flock may be infected due contact with infected animals directly or by indirectly and indirect contact with an infected environment. The disease is very rapid transmission when disease animal or these animals that suspected to infecting are in close area, due to contact with each other or through air droplets (Alexandersen et al. 2003). What is the role of sheep herd and what is the role of sheep in transmission of the disease when disease epidemics occur it is not quite clear. By the way, transmission of the diseasedue to sheep has been showed to be limited, but may be suspected sheep cause of the transmission of disease (Eble et al. 2015).

The mortality rates are alreadylow but rate of morbidity are high when FMD out break occurs, with the decrease in milk yield, meat production andpoor skin quality and cause abortion with repeat breeding problem in animals and causes in severe economic losses to the flock industry, especially in FMD-free countries of the world (Ko et al. 2012; Rajasekhar et al. 2013; Jeong et al. 2015). Vaccination is the only practicable method to control FMD in endemic countries, vaccines adjuvant with aluminium hydroxide or oil has been successfully used worldwide. But in countries free of FMD includes North and Central America, Europe, Japan, and Australia, control of the disease is based on the prevention and control of entering of the disease through tight regulation entrance and quarantine. So when disease entre into these areas, emergency vaccination may have to support,and should be controlling the movement of animals and use stamping out untilquarantine the disease (Hohlich et al,. 2003; Clavijo et al. 2004; Sharma et al. 2012; Bucafusco et al. 2014; Saravanan et al. 2015). Because FMD disease have several serotype and not cross-section between serotype so, vaccination generally does not protect against all serotypes, and even between some strains, thus the choice of correct strain of vaccineshould take in the vaccination to protection of the animals (Barnett et al. 2002; Uddowla et al. 2012). In this study we used immunostimulant drugs (levamisole, zinc and $\mathrm{AD}_{3} \mathrm{E}$ vitamin) with $\mathrm{FMD}$ vaccine to increase the immunity that produced in sheep.These three immunostimulants drugsand immunomodulatorssuch as LMS, zinc and vitamin combinations enhance the humoral and nonspecific cellular defence mechanisms in animals.

In the present study; we aimed to define how the immunostimulant drugs effect on level of immunoglobulins (IgM, IgG, IgA, IgE) in sheep when these immunostimulant drugs used together with FMD vaccine. The most effective drugs were also aimed to determine and compaction will also be made.

\section{MATERIALS and METHODS}

\section{Materials}

In this study, 40 femal sheep (1-3) years were selected from a flock of sheep in the region of Van. All routine clinical examinations were performed on the animals, according to the methods described in clinical examination procedures (Lovatt, 2010). After checking heart rate, respiratory rate, body temperature, mucous membrane and skin, 40 sheep were selected which were healthy and in good conditions. The data collected from selected sheep were kept in the record. Final report of the research project detailed above was approved by Yüzüncü Yıl University Animal Local Research Ethic Committee in the session held on 24.11.2016 (decision number 2016/11).

\section{Methods}

After checking all Physical examinations of each individual sheep: temperature, pulse, respiration, mucous membrane colour, all 40 selected sheep were in good condition and health. Then all clinical examinations were collected and the data obtained was recorded.

The 40 selected healthy sheep were divided into 4 groups. Each group consisted of 10 sheep. Blood and serum samples were taken from all animals from 0 days which was kept in tubesfor measuring serum levels of immunoglobulin and zinc. All serum and plasma samples in Eppendorf tubes were preserved in freezer $(-20 \stackrel{\circ}{\circ})$.

Food and mouth disease vaccine (AFTOVAC Oil ${ }^{\circledR}$ ) obtained from market and approved by Food Agriculture and Livestock (Republic of Turkey), was administered to all 4 groups of sheep in the following ways:

Group I. Only FMD vaccine (AFTOVAC Oil $\left.{ }^{\circledR}\right)(1 \mathrm{ml} \mathrm{SC}$ ) was used.

Group II. In this group, FMD vaccine (AFTOVAC Oil $\left.{ }^{\circledR}\right)(1 \mathrm{ml}$ SC) and levamisole tablet (5 $\mathrm{mg} / \mathrm{Kg}$ per oral) (Zelensin, Sanovel ${ }^{\circledR}$ ) were used.

Group III. In this group FMD vaccine (AFTOVAC Oil ${ }^{\circledR}$ ) (1 ml SC) and zinc tablet $(30 \mathrm{mg} / 50 \mathrm{Kg}$ per oral) (ZINCO $30 \mathrm{mg}$ Tab. BERKO ${ }^{\circledR}$ ) were applied.

Group IV. In this group, FMD vaccine (AFTOVAC Oil ${ }^{\circledR}$ ) (1 $\mathrm{ml} \mathrm{SC}$ ) and vitamin $\mathrm{AD}_{3} \mathrm{E}(\mathrm{IM})$ (ADEMIN-CEVA-DİF${ }^{\circledR}$ ) were injected.

After 21 days of applying the vaccines and immunostimulating drugs on all groups for measuring serum levels of immunoglobulin and zinc.

\section{Laboratory examinations \\ Haematological examinations}

Blood samples taken from all groups and preserved in EDTA-containing tubes and then analyzed by Veterinary Haematology (MS 4 -S). Blood parameters including total WBC, lymphocyte count (LYM), monocyte count (MONO), neutrophil count (NEUT), eosinophil count(EOS), red blood cell count (RBC), haemoglobin concentration (HGB), heamatocrit level (HCT) and platelet count (PLT) were measured on days 0 and 21 of the study.

\section{Measurement of immunoglobulin levels}

ELISA kits from COSABIO BIOTECH CO., Ltd. (CUSABIO ${ }^{\circledR}$, China) and ELISA reader (ELISA reader ${ }^{\circledR}$ - DAS) were used to determine Ig values.

\section{Measurement of zinc levels}

Serums were isolated from centrifuged blood samples and were then prepared for other biochemical examinations. Zinc levels were determined in the serum samples byAtomic Absorption Spectrometer (AAS) (Thermo ${ }^{\circledR}$ ).

\section{Statistical Analysis}

Descriptive statistics for the studied variables (characteristics) were presented as mean, standard deviation. After normality test with Kolmogorov-Smirnov test, One-way ANOVA was used for the comparison of means. And then Duncan multiple comparison test was carried out for determination of different groups' mean. In addition Paired t test was performed to compare before and after vaccination in each group. Statistical significance level was considered as 5\% and SPSS (ver: 13) statistical program was used for all statistical computations. 


\section{RESULTS}

\section{Clinical Findings}

All sheep used for the present study were healthy and had normal respiratory rate, normal heart rate $(70-80) \mathrm{bpm}$, normaltemperature $\left(38.3-39.9^{\circ} \mathrm{C}\right)$, normal lymph nodes, normal conjunctival colour, normal appetite and ruminal movement.

In this study, 30 independent food businesses were visited. Twenty-seven of these plants were restaurants or cafés which were serving animal originated foods while the other 3 were small businesses serving homemade.

\section{Haematological Findings}

Haematological findings in all excremental before and after vaccination in table 1 .

\section{Serological Findings}

Serum immunoglobulin level in the experimental sheep, before and after vaccination in table 2 .

\section{Zinc Measurement}

Serum levels of $\mathrm{Zn}$ in table 3.

Table 1. Descriptive statististics and comparison results for the haematological characteristics

\begin{tabular}{|c|c|c|c|c|c|c|}
\hline Parameters & Day & $\begin{array}{l}\text { Group I } \\
\text { [Only vac. }(n=10)]\end{array}$ & $\begin{array}{l}\text { Group II } \\
\text { [Vac.+LMS. }(n=10)]\end{array}$ & $\begin{array}{l}\text { Group III } \\
{[\text { Vac. }+\mathrm{Zn} \quad(\mathrm{n}=10)]}\end{array}$ & $\begin{array}{l}\text { Group IV } \\
{\left[\text { Vac. }+\mathrm{AD}_{3} \mathrm{E}\right.} \\
(\mathrm{n}=10)]\end{array}$ & $\mathbf{p}^{*}$ \\
\hline \multirow{2}{*}{ WBC $\left(10^{9} / \mathrm{L}\right)$} & 0 & $10.33 \pm 0.37$ & $9.18 \pm 0.87$ & $10.21 \pm 0.46$ & $10.85 \pm 0.87$ & 0,211 \\
\hline & 21 & $10.40 \pm 1.17$ & $8.78 \pm 0.78$ & $9.05 \pm 0.47$ & $10.06 \pm 0.87$ & 0,198 \\
\hline$p^{\#}$ & $\mathrm{P}$ & 0,258 & 0,343 & 0,061 & 0245 & \\
\hline \multirow{2}{*}{ LYM $\left(10^{9} / \mathrm{L}\right)$} & 0 & $2.46 \pm 0.47$ & $2.71 \pm 0.26$ & $3.15 \pm 0.41$ & $3.25 \pm 0.36$ & 0,058 \\
\hline & 21 & $3.06 \pm 0.49$ & $2.96 \pm 0.32$ & $2.81 \pm 0.30$ & $2.66 \pm 0.48$ & 0,210 \\
\hline $\mathrm{p}^{\#}$ & & 0,226 & 0,555 & 0,555 & 0,065 & \\
\hline \multirow{2}{*}{$\begin{array}{l}\text { MONO } \\
\left(10^{9} / \mathrm{L}\right)\end{array}$} & 0 & $1.31 \pm 0.06$ & $1.35 \pm 0.16$ & $1.41 \pm 0.14$ & $1.43 \pm 0.25$ & 0,140 \\
\hline & 21 & $1.13 \pm 0.18$ & $1.20 \pm 0.85$ & $1.15 \pm 0.03$ & $1.45 \pm 0.13$ & 0,161 \\
\hline $\mathrm{p}^{\#}$ & & 0,010 & 0,587 & 0,010 & 0,396 & \\
\hline \multirow{2}{*}{ NEUT $\left(10^{9} / \mathrm{L}\right)$} & 0 & $5.90 \pm 0.76$ & $5.03 \pm 0.75$ & $5.58 \pm 0.48$ & $6.10 \pm 0.54$ & 0,058 \\
\hline & 21 & $6.26 \pm 0.53 \mathrm{a}$ & $4.53 \pm 0.58 \mathrm{~b}$ & $4.88 \pm 0.47 \mathrm{~b}$ & $5.88 \pm 0.98 \mathrm{a}$ & 0,001 \\
\hline $\mathrm{p}^{\#}$ & & 0,633 & 0,036 & 0,010 & 0,746 & \\
\hline \multirow{2}{*}{$\operatorname{EOS}\left(10^{9} / \mathrm{L}\right)$} & 0 & $0.10 \pm 0.00$ & $0.08 \pm 0.08$ & $0.07 \pm 0.08$ & $0.07 \pm 0.08$ & 0,373 \\
\hline & 21 & $0.03 \pm 0.06$ & $0.08 \pm 0.16$ & $0.03 \pm 0.05$ & $0.07 \pm 0.05$ & 0,005 \\
\hline $\mathrm{p}^{\#}$ & & 0,010 & 0,368 & 0,010 & 0,914 & \\
\hline \multirow{2}{*}{$\mathrm{RBC}\left(10^{9} / \mathrm{L}\right)$} & 0 & $8.42 \pm 1.75$ & $8.39 \pm 1.45$ & $8.83 \pm 1.05$ & $8.47 \pm 0.91$ & 0,176 \\
\hline & 21 & $8.52 \pm 1.53$ & $8.84 \pm 1.23$ & $8.36 \pm 0.78$ & $8.01 \pm 0.46$ & 0,081 \\
\hline$p^{\#}$ & & 0,615 & 0,091 & 0,032 & 0,751 & \\
\hline \multirow{2}{*}{ HGB (g/dl) } & 0 & $9.30 \pm 1.35$ & $9.73 \pm 1.10$ & $10.13 \pm 1.27$ & $9.87 \pm 1.23$ & 0,653 \\
\hline & 21 & $9.27 \pm 0.96$ & $10.13 \pm 1.17$ & $9.43 \pm 1.01$ & $9.13 \pm 0.25$ & 0,068 \\
\hline$p^{\#}$ & & 0,571 & 0,724 & 0,103 & 0,696 & \\
\hline HCT & 0 & $27.90 \pm 4.04$ & $29.20 \pm 3.30$ & $30.40 \pm 3.81$ & $29.60 \pm 3.68$ & 0,428 \\
\hline$(\%)$ & 21 & $27.80 \pm 2.88$ & $30.40 \pm 3.51$ & $28.30 \pm 3.03$ & $27.40 \pm 0.75$ & 0,605 \\
\hline$p^{\#}$ & & 0,614 & 0,619 & 0,213 & 0,069 & \\
\hline \multirow{2}{*}{$\operatorname{PLT}\left(10^{9} / \mathrm{L}\right)$} & 0 & $202.33 \pm 94.83 \mathrm{~b}$ & $282.66 \pm 77.47 \mathrm{~b}$ & $314.16 \pm 41.58 \mathrm{ab}$ & $397.66 \pm 70.73 \mathrm{a}$ & 0,010 \\
\hline & 21 & $387.66 \pm 82.32 \mathrm{~b}$ & $370.83 \pm 48.77 \mathrm{~b}$ & $371.00 \pm 40.33 b$ & $520.83 \pm 61.94 \mathrm{a}$ & 0,010 \\
\hline$p^{\#}$ & & 0,010 & 0,016 & 0,010 & 0,010 & \\
\hline
\end{tabular}

Different lower cases at the same row represent statististically significant differences among the groups (p<0.05).p\#: $p$ value of Paired t test, $\mathrm{p}^{*}$ : $\mathrm{p}$ values of ANOVA 
Table 2. Serum immunoglobulin level in the experimental sheep, before and after vaccination

\begin{tabular}{|c|c|c|c|c|c|c|}
\hline Parameters & Day & $\begin{array}{l}\text { Group I } \\
\text { [Only vac. }(n=10)]\end{array}$ & $\begin{array}{l}\text { Group II } \\
\text { [Vac. + LMS. }(n=10)]\end{array}$ & $\begin{array}{l}\text { Group III } \\
{[\text { Vac. }+ \text { Zn }(n=10)]}\end{array}$ & $\begin{array}{l}\text { Group IV } \\
{\left[\text { Vac. }+\mathrm{AD}_{3} \mathrm{E}(\mathrm{n}=10)\right]}\end{array}$ & $\mathbf{p}^{*}$ \\
\hline \multirow{2}{*}{$\operatorname{IgM}(\mu \mathrm{g} / \mathrm{mL})$} & 0 & $52.07 \pm 6.57 \mathrm{a}$ & $45.17 \pm 6.07 \mathrm{a}$ & $42.08 \pm 2.91 \mathrm{~b}$ & $35.61 \pm 5.75 \mathrm{~b}$ & 0,010 \\
\hline & 21 & $56.42 \pm 7.13 \mathrm{a}$ & $48.89 \pm 4.78 \mathrm{a}$ & $52.09 \pm 5.66 \mathrm{a}$ & $35.67 \pm 2.37 \mathrm{~b}$ & 0,010 \\
\hline $\mathrm{p}^{\#}$ & & 0,803 & 0,113 & 0,010 & 0,632 & \\
\hline \multirow{2}{*}{$\operatorname{IgG}(\mu \mathrm{g} / \mathrm{mL})$} & 0 & $25.53 \pm 1.65 \mathrm{~b}$ & $33.97 \pm 7.23 \mathrm{~b}$ & $42.99 \pm 3.70 \mathrm{a}$ & $28.81 \pm 0.30 \mathrm{~b}$ & 0,010 \\
\hline & 21 & $30.35 \pm 5.21 \mathrm{~b}$ & $44.28 \pm 6.28 \mathrm{a}$ & $49.49 \pm 7.48 \mathrm{a}$ & $25.64 \pm 2.30 \mathrm{~b}$ & 0,010 \\
\hline $\mathrm{p}^{\#}$ & & 0,068 & 0,548 & 0,010 & 0,302 & \\
\hline \multirow{2}{*}{$\operatorname{IgA}(\mu \mathrm{g} / \mathrm{mL})$} & 0 & $15.47 \pm 3.25 \mathrm{~b}$ & $34.87 \pm 4.78 \mathrm{a}$ & $24.69 \pm 5.86 \mathrm{~b}$ & $30.61 \pm 5.35 \mathrm{a}$ & 0,010 \\
\hline & 21 & $46.36 \pm 10.91 \mathrm{a}$ & $35.17 \pm 5.81 \mathrm{~b}$ & $33.68 \pm 9.76 \mathrm{~b}$ & $28.38 \pm 3.37 \mathrm{~b}$ & 0,010 \\
\hline$p^{\#}$ & & 0,010 & 0,066 & 0,063 & 0,057 & \\
\hline \multirow{2}{*}{$\operatorname{IgE}(\mathrm{ng} / \mathrm{mL})$} & 0 & $506.42 \pm 192.01$ & $445.22 \pm 161.02$ & $424.17 \pm 253.21$ & $554.36 \pm 103.41$ & 0,473 \\
\hline & 21 & $578.73 \pm 298.12 \mathrm{~b}$ & $690.79 \pm 104.15 \mathrm{a}$ & $732.40 \pm 101.12 \mathrm{a}$ & $769.05 \pm 268.02 \mathrm{a}$ & 0,041 \\
\hline $\mathrm{p}^{\#}$ & & 0,201 & 0,010 & 0,010 & 0,010 & \\
\hline
\end{tabular}

Different lower cases at the same row represent statististically significant differences among the groups $(p<0.05) \cdot p^{\#}$ : $p$ value of Paired t test, $p^{*}: p$ values of ANOVA

Table 3. Serum levels of $\mathrm{Zn}$ in experimental sheep, on days 0 and 21

\begin{tabular}{|c|c|c|c|c|c|c|c|}
\hline Parameter & Day & $\begin{array}{l}\text { Group I } \\
\text { [Only vac. }(n=10)]\end{array}$ & $\begin{array}{l}\text { Group II } \\
{[\text { Vac. }} \\
(n=10)]\end{array}+$ & LMS. & $\begin{array}{l}\text { Group III } \\
{[\text { Vac. }+ \text { Zn }(n=10)]}\end{array}$ & $\begin{array}{l}\text { Group IV } \\
{\left[\text { Vac. }+\mathrm{AD}_{3} \mathrm{E}\right.} \\
(\mathrm{n}=10)]\end{array}$ & $\mathbf{p}^{*}$ \\
\hline \multirow[t]{2}{*}{$\mathrm{Zn}(\mathrm{mg} / \mathrm{L})$} & 0 & $0.72 \pm 0.17$ & $0.57 \pm 0.11$ & & $0.64 \pm 0.13$ & $0.50 \pm 0.11$ & 0,071 \\
\hline & 21 & $0.60 \pm 0.12$ & $0.70 \pm 0.23$ & & $0.88 \pm 0.21$ & $0.65 \pm 0.17$ & 0.059 \\
\hline $\mathrm{p} \#$ & & 0,084 & 0,348 & & 0,254 & 0123 & \\
\hline
\end{tabular}

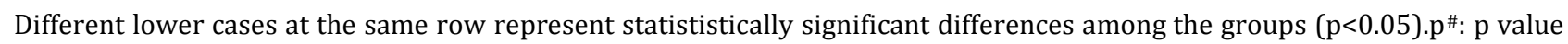
of Paired t test, $\mathrm{p}^{*}$ : $\mathrm{p}$ values of ANOVA

\section{DISCUSSION}

Foot and mouth disease is a severe infectious disease of animals.FMDV is a small, positive-sense RNA virus in the Family of Picornaviridaeand genus Aphthovirus, characterised by high body temperature, vesicles appear on the tongue, mucosa and feet.When young animals infected it cause sudden death (Barnett et al. 2002; Wong et al. 2003; Ko et al. 2012; Horsington et al. 2015).

Vaccination is the only practicable method to control FMD in endemic countries.Vaccines adjuvant with aluminium hydroxide or oil has been successfully used worldwidein the regions including Europe, Japan, Australia, and North and Central America. Controlling and preventing the FMD is based on the prevention of introducing the virus, through tight importation regulation and quarantine. In case of a disease entry into these areas, emergency vaccination may be used, controlling the movement of animal and stamping out for eradication of the disease are also required (Hohlich et al. 2003; Clavijo et al. 2004; Sharma et al. 2012; Bucafusco et al. 2014; Saravanan et al. 2015).

Transmission of the virus occursinside or among herds; this is different among sheep herds and cattle herds. Vaccination affectstransmission of FMD and clinical disease differ among the animal species.

Before taken blood samples from all sheep, all animals examined for any abnormality in respiratory rate, body temperature, heart rate, lymph nodes and eye mucus membrane. Blood was taken and FMD vaccineand immunostimulant agents were given to the different groups. After blood sample were taken, haematological examinations were done immediately and serum samples were also prepared and stored at $-20{ }^{\circ} \mathrm{C}$ for serology. In this study, $\mathrm{LMS}, \mathrm{Zn}$ and vitamin $\mathrm{AD}_{3} \mathrm{E}$ were used with FMD vaccine to see whether they enhance immunity or not and also to made a comparison among these three agents regarding their immunostimulant activity.

After haematological examination of blood in day 0 , it was found that all blood parameters were normal according to Jackson and Cockcroft (2002). According to the result in table 1 we found that in group of LMS, WBC decreased after 21 day but was not statistically significant. This result was similar to those of Pekmezci and Cakiroglu (2009), Shah et al. (2011) and Raina and Sachar (2014). In zinc group, the level of WBC decreased but was not statistically significant. This result was similar to those of Ramulu et al. (2015). Level of WBC not changed $\mathrm{AD}_{3} \mathrm{E}$ group after 21 day. This result was similar to those of Pekmezci and Cakiroglu (2009).

Lymphocytelevel decreased after 21 day but not statistically significant. This result was similar to those of Mohri et al. (2005), Pekmezci and Cakiroglu, (2009) and Raina and Sachar, (2014). Level of NEUT in groups of levamisole and zinc decreased in 21 day but was not statistically significant.In vitamin $\mathrm{AD}_{3} \mathrm{E}$ group, the level of NEUT decreasedafter 21 days and statistically was significant $(\mathrm{P}<0.05)$, this result was in agreement to the result of Shah et al. (2011) but different from those of Spears (2000) that supplementation of vitamin and $\beta$ carotene did not consistently affect neutrophil activity. 
The main function of neutrophils is chemotaxis and phagocytosis with subsequent destruction of the bacteria. Neutrophilia occurs mostly in infectious diseases, particularly acute bacterial infections. No significant changes occurred in eosinophil counts in LMS group. This result was similar to those of Pekmezci and Cakiroglu (2009). EOS however did not change notablyin Zn group. This result was similar to those of Raina and Sachar (2014). RBC level non-significantly declined in animals treated with $\mathrm{Zn}$. This result was similar to those of Raina and Sachar (2014). Changes in RBC were still within normal range. HGB in levamisole group increased but statistically not significant. This result was similar to those of Pekmezci and Cakiroglu (2009). Decrease in HGB and HCT might be due to RBC lysis/destruction and greater prevalence of erythroblasts (immature RBCs) in the general circulation in zinc treated animal. Support for the present viewpoint can be derived from the findings by Raina and Sachar (2014). Increased level of PLT in sheep treated with $\mathrm{AD}_{3} \mathrm{E}$ was not statistically significant. Increased level of PLT in sheep treated with LMS was statistically significant $(\mathrm{P}<0.05)$. This result was differentfrom those of Pekmezci and Cakiroglu (2009). Increased level of PLT was statistically significant $(\mathrm{P}<0.05)$ in sheep treated with $\mathrm{Zn}$. This result was differentfrom those of Raina and Sachar (2014). A majorcomponent of platelet alpha granules is thrombospondin that plays animportant role in blood coagulation. Also, plateletderived endothelial cellgrowth factor enhances the growth and chemotaxis of endothelialcells in vitro and angiogenesis in vivo (Eales, 2003). The present study define how the immunostimulants effectedthe level of Igsin sheep, by measuring the level of Ig types (IgM, IgG, $\operatorname{IgA}$ and IgE) in the serum of four groups of experimental sheepand compared between level of Igs before and after using the vaccines and immunostimulant drugs.

Group I only vaccinated against FMD, levels of IgM, IgG, IgA and IgE were increased after 21 days. This explained that vaccine has worked properly and immunne response against FMD was enhanced. Levamisole is an imidazothiazole derivative and used commonly as an anthelminthic against a broad range of nematodes in different hosts including ruminant, horses, dogs, chickens and humans. Renoux and Renoux (1971) was first reported the immune stimulatory effect of LMS and used to enhance the protection of a Brucella vaccine.

Based on the investigation of Gopalakannan and Arul (2006) it was evident that LMS (250 mg/kgof diet) certainly promoted the nonspecific immunity of Cyprinuscarpioin ponds. Thus LMS acts as an immunostimulant that appears to improve the immune status and growth of $\mathrm{C}$. carpioin fish farms. It is hoped that this base line information will be of potential use in fish farming. In group II, levels of IgM and IgA increased but were not statistically significant, and level of IgG increased and was statistically significant $(\mathrm{P}<0.05)$. IgE increased and was statistically significant $(\mathrm{P}<0.001)$. When LMS used with killed viruses can induce IgG production more rapidly and at higher levels, LMS injected with a DNA vaccine against the FMDV stimulated both humoral and cellular immune responses in conjunction with a strong production of IFN- $\gamma$, (Stelletta et al. 2004; Kang et al. 2005; $\mathrm{Fu}$ et al. 2016). Levamisole and vitamin $\mathrm{E}$ administered groups resulted with high concentrations of IgM than control calves on day 22 and again increaselevel of IgG than that of control calves on day 1, 8, 15 and 22 of the trial (Pekmezci and Cakiroglu, 2009).
The effects of LMS on the immune system is complex, and stimulate T-cell responses by enhancing T-cell activation andproliferation, enhance formation of antibodies to various antigens, promote macrophage and monocyte functions such as phagocytosis and chemotaxis and increased neutrophil locomotion, adherence, and chemotaxis (Ocal et al. 2007; Sadigh-Eteghad et al. 2011). According to Stelletta et al. (2004), Kang et al.(2005), Ocal et al. (2007), Pekmezci and Cakiroglu (2009), SadighEteghad et al. (2011) and Fu et al. (2016), LMS enhances immune system and increases level of the IgG significantly but increased level of IgE might be due to FMD vaccine since it contains adjuvant.

The immunomodulatory importance of $\mathrm{Zn}$ was first described by Brazão et al. (2015) who displayed that Zn may act in cell proliferation, DNA metabolism and repair, oxidative defence and cellular signalling pathways, besides being a protective agent against the apoptosis, furthermore, it has been shown that apoptosis is potentiated in $\mathrm{Zn}$ deficiency (Brazão et al. 2015). Animal immunityalso affected by the level of $\mathrm{Zn}$, ithas immunostimulatory activities and keeps the homeostasis of oxidation/reduction. Among the $\mathrm{Zn}$ sources studied, organic $\mathrm{Zn}$ sources showed better immune activity compared to $\mathrm{ZnSO} 4$ (Lin et al. 2013). In group III, increased level of $\operatorname{IgA}$ and $\operatorname{IgG}$ were not statistically significant but the level of IgM was statistically significant $(\mathrm{P}<0.05)$ and IgE increased and statistically was significant $(\mathrm{P}<0.001)$. These finding resembles Schafer et al. (2015). IgG and IgM are the major Igs which are responsible in the complement activation, opsonisation, neutralization of toxins (Shah et al. 2011). Zn deficiency reduced the concentration of IgE and IgG in rats that infected with gastrointestinal nematodes. Thus, the increase in the levels of these Igs in supplemented animals may be initially a result of better mineral supply of zinc (Schafer et al. 2015). And the results were similar to Brazão et al. (2015) it has been indicated that $\mathrm{Zn}$ supplementation causes changes in humoral immunity such as stimulation of B-lymphocytes and increased serum Igs levels like IgA and IgG. Thus, the intracellular killing of parasites are triggered or stimulated by zinc treatment. Development of B cells from immature and pre-mature $B$ cells and production of antibody affected by $\mathrm{Zn}$ deficiency. Zn deficiency reduces PMN cells chemotaxis and inversely a super-physiological $\mathrm{Zn}$ concentration $(500 \mu \mathrm{M})$ generates PMN chemotaxis in vitro. A $\mathrm{Zn}$ deficiency decreases phagocytosis but $\mathrm{Zn}$ supplementation increases it (Bonaventura et al. 2015). Zn decreases $\mathrm{T}$-cell proliferation and causes a shift in the $\mathrm{T}$ helper Th1/Th2-balance towards a Th2 response. Thus, especially $\mathrm{T}$ cell-mediated cellular immune responses are usually affected by imbalanced $\mathrm{Zn}$ levels (Rosenkranzet al. 2015). $\mathrm{Zn}$ is also an important factor responsible for the maintenance of physiological balance between the Th1, Th2 and Th17 lymphocyte subtypes. Zinc deficiency decreases the production of cytokines by Th1 and Th17 cells, but has lower effect on the Th2 response (Młyniecet al. 2015). The increased serum globulin concentrations by Zn supplementation implies better immune response with $\mathrm{Zn}$ supplementation. An increase in plasma globulin concentration with $\mathrm{Zn}$ supplementation was also observed in lactating Friesian cows (Ramuluet al. 2015). According to Bonaventura et al. (2015), Brazão et al.(2015), Młyniec et al. (2015), Ramulu et al. (2015), Rosenkranz et al. (2015) and Schafer et al. (2015) use of vaccine and $\mathrm{Zn}$ promotes immune system and increased level of IgG and IgM. But increase of IgE in the present study might be due toadjuvant in FMD vaccine. 
A statistically significant variation was found in level of IgG between LMS and $\mathrm{Zn}$ groups in the same line $(\mathrm{P}<0.05)$ day 21 . Based on this results $\mathrm{Zn}$ was more effective than LMS on the IgG level. In group IV, IgM was not changed. Levels of IgG and IgA decreased were not statistically significant. Level of IgE increased was statistically significant $(\mathrm{P}<0.001)$. Kizil and Gul $(2008)$ used vitamin $\mathrm{AD}_{3} \mathrm{E}$ with FMD vaccine to a group of cattle. The result was a good protection against FMD. This result might explain the antistress property of vitamin $\mathrm{AD}_{3} \mathrm{E}$ which has minimized the negative effects of the vaccination Gammaz et al. (2010) studied the effect of vitamin $\mathrm{AD}_{3} \mathrm{E}$ on growth performance in fish and found that, besides its positive effect on growth, it has also enhanced defense mechanism against diseases via its role in both innate and adaptive immune responses. Vitamin E functions as an antioxidant that scavenges free radicals and protects against lipid peroxidation. The role of vitamin $\mathrm{E}$ as an antioxidant may explain its importance in immune responses (Spears, 2000). Combination between multivitamins $\mathrm{AD}_{3} \mathrm{E}$ with Newcastle disease vaccine causes increase in antibody titer against Newcastle disease. This element is important for the development of the immune cell structure and eicosanoid formation (Al-zuhairy and Jameel, 2014). When Newcastle disease virus causes infection in poultry with vitamin A deficiency, the result wasa decrease in IgG titres and the risk for secondary infection may increase (West et al. 1991). These results were similar to those of West et al.(1991) but were in contrast to those of Kizil and Gul (2008). During normal activities of the cells, oxidant molecules produced continuously in the body and vitamin A and vitamin Ehave been reported toremove these oxidant molecules. High dose of vitamin $E$ has been shown to enhance immune response, neutrophil activity and cellular humoral immunity (Kizll and Gul, 2008). Zn deficiency in animals may occur as a result of its deficiency in soil and pasture, or may be due to stressful conditions such as vaccinations or diseases causing $\mathrm{Zn}$ depletion in the body tissues and fluids. Immunity of animal also effect by the Level of Znin dietary diet, organic $\mathrm{Zn}$ sources showed better immune activity compared to ZnSO4 (Lin et al. 2013).

\section{CONCLUSION}

it has been concluded that the application of LMSor Zn with FMD vaccine, has positive effects on sheep Igs especially IgG,IgM and IgE, and that animals respond early to infection after use these drugs with FMD vaccine during vaccination. Thus, it is advised to use LMS and $\mathrm{Zn}$ with vaccines to potentiate immune responses.

\section{ACKNOWLEDGEMENT}

This research is summarized from the master thesis with the same name, supported by YüzüncüYıl University Presidency of Scientific Research Projects (project number: TYL-2016-5460).

\section{REFERENCES}

Alexandersen S, Zhang Z, Donaldson AI, Garland AJM (2003). The Pathogenesis and Diagnosis of Foot-and-Mouth Disease, J Comp Path, $129,1-36$.

Al-zuhairy MA, Jameel YJ (2014).Effect of ND Vaccine, Multivitamins $\mathrm{AD}_{3} \mathrm{E}$, and Omega-3 on Performance and Immune Response of Broilers. Mrvsa, 3, 1, 42-50.

Barnett PV, Cox SJ, Aggarwal N, Gerbe H, McCullough KC (2002). Further studies on the early protective responses of pigs following immunisation with high potency foot and mouth disease vaccine. Vaccine, 20, 3197-3208.
Bonaventura $P$, Benedetti G, Albarède F, Miossec $P$ (2015). Zinc and its role in immunity and inflammation. Autormmun Rev, 14, 277-285.

Brazão V, Filipin MDV, Santello FH, et al. (2015). Immunomodulatory properties and anti-apoptotic effects of zinc andmelatonin in an experimental model of chronic Chagas disease. Immunobiology, 220, 626-633.

Bucafusco D, Giacomo SD, Pega J et al. (2014). Influence of antibodies transferred by colostrum in the immune responses of calves to current foot-and-mouth disease vaccines. Vaccine, 32, 6576-6582.

Clavijo A, Wright P, Kitching $\mathbf{P}$ (2004). Developments in diagnostic techniques for differentiating infection from vaccination in foot and mouth disease. Vet J, 167, 9-22.

Eales LJ (2003). Immunology for Life Scientists, Second Edition, chapter one. Chichester, England. 1-298.

Eble'P.L, Orsel K, Hemert-Kluitenberg FV, Dekker A (2015).Transmission characteristics and optimal diagnostic samples to detect an FMDV infection in vaccinated and non-vaccinated sheep. Vet Microbiol, 177, 69-77.

Fu Y, Wang T, Xiu L et al. (2016). Levamisole promotes murine bone marrow derived dendritic cellactivation and drives Th1 immune response in vitro and in vivo. IntImmunopharmacol, 31 57-65.

Gammaz HA, Fayez MM, Abdel-Naby EA (2010). Effect of sanguinarine and vitamins AD3E on growth performance in Cyprinus carpio. Suez Canal Vet Med J, 15, 1, 27-44.

Gopalakannan A, Arul V (2006). Immunomodulatory effects of dietary intake of chitin, chitosan and levamisole on the immune system of Cyprinus carpio and control of Aeromonas hydrophila infection in ponds. Aquaculture, 255, 179-187.

Hohlich BJ, Wiesmuller KH, Haas B, et al. (2003).Induction of an antigenspecific immune response and partial protection of cattle against challenge infection with foot-and-mouth disease virus (FMDV) after lipopeptide vaccination with FMDV-specific B-cell epitopes. J Gen Viro, 84, 3315-3324.

Horsington J, Zhang Z, Bittner $\mathbf{H}$ et al. (2015). Early protection in sheep against intratypic heterologous challengewith serotype 0 foot-andmouth disease virus using high-potency,emergency vaccine. Vaccine, $33,422-429$.

Jackson PGG,Cockcroft PD(2002). Clinical Examination of Farm Animals, Appendix 2 Laboratory Reference Values: Haematology, 301-302

Jeong K, Lee J, Park S et al. (2015). Synthesis and in-vitro evaluation of 2 amino-4-arylthiazole as inhibitor of 3D polymerase against foot-andmouth disease (FMD).Eur J Med Chem, 102, 387-397.

Kang Y, Jin H, Zheng G et al. (2005). The adjuvant effect of levamisole on killed viral vaccines. Vaccine, 23, 5543-5550.

Kızıl O, Gul Y (2008). Effects of vitamin AD3E and C on immune responses of cattle to trivalent foot and mouth disease vaccine.Revue Med Vet 159, 12, 599-602.

Ko Y, Lee H, Park J et al. 2012). Field application of a recombinant proteinbased ELISA during the 2010 outbreak of foot-and-mouth disease type A in South Korea. J Virol Methods, 179, 265- 268.

Lin S, Lin X, Yang Y, Li F, Luo L (2013). Comparison of chelated zinc and zinc sulfate as zinc sources for growth and immune response of shrimp (Litopenaeusvannamei). Aquaculture, 406-407, 79-84.

Lovatt FM (2010). Clinical examination of sheep. Small Ruminant Res, 92, 72-77.

Młyniec K, Trojan E, Slusarczyk J et al. (2015). Immune malfunction in the GPR39 zinc receptor of knockout mice: Its relationship to depressive disorder.J Neuroimmunol, 10,1016,12,001.

Mohri M, Seifi HA, Sani SHZ (2005). Effects of oral administration of levamisole on non-specific immunity, serum proteins and health in normal colostrum-fed neonatal dairy calves.CompClin Path, 13, 132136.

Ocal G, Kokcu A, CetinkayaM.B, TosunM, Kefeli M, Kandemir B (2007). Efficacy of levamisole on experimental endometriosis.Int GynecolObstet, 99, 38-42.

Paton DJ, Füssel AE, Vosloo W, Dekker A, Clercq KD (2014). The use of serosurveys following emergency vaccination, to recover the status of "foot and mouth disease free where vaccination is not practised".Vaccine, 32, 7050-7056.

Pekmezci D, Cakiroglu D (2009). Investigation of Immunmodulatory effects of levamisole and vitamin $\mathrm{E}$ on Immunity and some blood parameters in newborn Jersey calves. Vet Res Commun, 33, 711-721.

Raina Sh and Sachar A (2014).Effect of Heavy Metal, Zinc and Carbamate Pesticide, Sevin on Haematological Parameters of Fish, Labeo Boga.IntJInnov Res SciEngTechnol, 3, 2319-8753.

Rajasekhar R, Hosamani M, Basagoudanavar SH et al. (2013). Rescue of infective virus from a genome-length cDNA clone of the FMDV serotype 0 (IND-R2/75) vaccine strain and its characterization. Res Vet Sci, 95 291-297. 
Ramulu SP, Nagalakshmi D, Kumar MK (2015). Effect of zinc supplementation on haematology and serum biochemical constituents in Murrah buffalo calves.Indian J Anim Res, 49, 4, 482-486.

Renoux G, Renoux M (1971). Effect immunostimulant d'un imidothiazole dans l'immunization des souris contre I'infection per Brucella abortus". Cr. Acad. Sci. (D) Paris 272:349-350.

Rosenkranz E, Maywald M, Hilgers RD et al. (2015). Induction of regulatory $\mathrm{T}$ cells in Th1-/Th17-driven experimental autoimmune encephalomyelitis by zinc administration. J Nutr Biochem, 10, 1016, 11 010.

Sadigh-Eteghad S, Khayat-Nuri H, Abadi N, Ghavami S, Golabi M Shanebandi D (2011). Synergetic effects of oral administration of levamisole and Echinacea purpurea on immune response in Wistar rat. Res Vet Sci, 91 82-85.

Saravanan P, Sreenivasa BP, Selvan RPT et al. (2015). Protective immune response to liposome adjuvanted high potency foot-andmouth disease vaccine in Indian cattle. Vaccine, 33, 670-677.

Schafer AS, Leal MLR, Molento M.B, et al. (2015). Immune response of lambs experimentally infected with Haemonchus contortus and parenterally treated with a combination of zinc and copper. Small Rumin Res, 123, 183-188.
Shah D, Londheva, Mazumder R, Parikh R (2011). Can levamisole alone maintain the immunity. Int J Pharm Pharm Sci, 0975-1491 3, 2.

Sharma GK, Mohapatra JK, Pandey LK et al. (2012). Immunodiagnosis of foot and mouth disease using mutated recombinant $3 \mathrm{ABC}$ polyprotein in a competitive ELISA. J Virol Methods, 185, 52- 60.

Spears JW (2000). Micronutrients and immune function in cattle. Nutr Soc, $59,587-594$.

Stelletta C, Cuteri V, Bonizzi L et al. (2004). Effect of levamisole administration on bluetongue vaccination in sheep. Vet Ital, 40, 4, 635.

Uddowla S, Pacheco J M, Larson C et al. (2013). Characterization of a chimeric foot-and-mouth disease virus bearing a bovine erhinitis $\mathrm{B}$ virus leader proteinase. Virology, 447, 172-180.

West CE, Rombout JHWM, Zijpp AJV, Sijtsma SR (1991). Vitamin A and immune function.Proc NutrSoc, 50, 251-262.

Wong HT, Cheng SC-S, Sin FW-Y, Chan EW-C, Sheng Z-T, Xie YA (2003) DNA vaccine against foot-and-mouth disease elicits an immune response in swine which is enhanced by co-administration with interleukin-2. Vaccine, 20, 2641-2647. 